\title{
Analisis Biaya Konstruksi Balok Beton Gradasi dengan Penggunaan Tulangan Maksimum
}

\author{
M. Mirza Abdillah Pratama \\ Jurusan Teknik Sipil Universitas Negeri Malang, Indonesia \\ E-mail: mirza.abdillah.ft@um.ac.id
}

Received 03 May 2021; Reviewed 16 July 2021; Accepted 03 August 2021

Journal Homepage: http://jurnal.borneo.ac.id/index.php/borneoengineering

\begin{abstract}
Reinforced concrete beam design using maximum reinforcement should be avoided because of the risk of brittle failure. However, structural designer often encounter design limitations for designing elements with minimal dimensions so that the use of the maximum reinforcement ratio is unavoidable. The structural designer should quarantee that the value of the tensile reinforcement strain exceeds its yield point when it experiences a failure. In this study, the author intend to further analyze the cost analysis of the resulting performance of graded concrete beams with the maximum use of reinforcement. The beams were designed with sizes $1720 \times 130 \times 260 \mathrm{~mm}$ and $1400 \times 130 \times 195 \mathrm{~mm}$, and were tested using the four-point bending method. The results showed that 1) With a dimension ratio of 2/3, an additional construction cost of $3.69 \%$ would increase the beam performance by $3.57 \%$ if the rebars were designed with the respect to the lowest concrete strength;2) The application of concrete gradation in beams can reduce work costs by up to $25.32 \%$ with a performance compensation of $33.91 \%$ for beams with a dimension ratio of $1 / 2$ which are designed with the respect to the highest concrete strength. 3) Graded concrete beam can optimize the cost of the work without significantly compensating for the structural performance, especially at maximum reinforcement usage.
\end{abstract}

Keywords: reinforced concrete beam; graded concrete beam; maximum load; cost

\begin{abstract}
Abstrak
Desain tulangan maksimum merupakan konsep desain yang harus dihindari karena risiko terhadap kegagalan getas. Namun demikian, perencana struktur kerap kali mendapati batasan desain untuk merancang elemen dengan dimensi minimalis sehingga penggunaan rasio tulangan maksimum menjadi tidak terhindarkan. Hal tersebut masih diperkenankan dengan tetap memperhatikan nilai regangan tulangan tarik agar melampaui titik lelehnya ketika mengalami kegagalan. Pada penelitian ini, penulis bermaksud untuk menganalisis lebih lanjut terkait analisis biaya terhadap kinerja yang dihasilkan dari balok beton gradasi dengan penggunaan tulangan maksimum. Balok didesain dengan ukuran $1720 \times 130 \times 260 \mathrm{~mm}$ dan $1400 \times 130 \times 195 \mathrm{~mm}$, dan diuji lentur dengan metode four point bending. Hasil penelitian menunjukkan bahwa 1) Dengan rasio dimensi 2/3, penambahan biaya konstruksi sebesar 3.69\% akan meningkatkan kinerja balok sebesar 3.57\% apabila pembesiannya didesain terhadap mutu beton terendahnya; 2) Penerapan gradasi mutu dapat menurunkan biaya pekerjaan hingga $25.32 \%$ dengan kompensasi kinerja sebesar $33.91 \%$ pada balok dengan rasio dimensi 1/2 yang pembesiannya didesain terhadap mutu beton tertingginya; 3) Balok gradasi dapat mengoptimasi biaya pekerjaan tanpa mengkompensasi kinerja struktur secara signifikan khususnya pada penggunaan tulangan maksimum.
\end{abstract}

Kata kunci: balok beton gradasi, tulangan maksimum, kapasitas beban, biaya 


\section{Pendahuluan}

Teknologi bidang konstruksi telah mengalami perkembangan pesat. Hal tersebut mendorong adanya upaya penyesuaian dalam hal kualitas, material, ekonomi, serta faktor keamanan yang diberlakukan dalam desain struktur. Balok beton bertulang merupakan elemen struktur yang berperan dalam menahan beban eksternal dan berat sendiri, dalam bentuk momen dan gaya geser. Pada tahapan desain, tegangan lentur yang terjadi pada balok menjadi parameter dalam penetapan dimensi penampang balok. Penentuan dimensi balok diharapkan mampu memikul beban secara optimal sehingga tercapai balok yang memenuhi servisabilitas yang sesuai dengan standar yang berlaku. Penentuan dimensi balok tersebut harus mempertimbangkan kinerja dan biaya, di mana balok dirancang dengan kekuatan sesuai kebutuhan namun tetap mengupayakan biaya pelaksanaan yang ekonomis.

Kurda (2019) mengatakan bahwa untuk menghasilkan desain yang ekonomis diperlukan proses optimasi. Dalam desain balok beton bertulang, optimasi dapat dilakukan dengan berbagai alternatif di antaranya dengan desain penampang ramping dan penggunaan tulangan dalam ambang maksimum. Harapannya, dapat diperoleh harga pekerjaan struktur yang murah, namun tetap memenuhi faktor keamanan yang disyaratkan. Dalam hal value engineering, diperlukan proses desain yang panjang dengan berbagai pertimbangan guna mampu mengoptimalkan pengeluaran biaya suatu proyek infrastruktur. Pemilihan material turut mengambil peran dalam penentu keberhasilan implementasi di suatu proyek. Melalui value engineering, diharapkan pengeluaran biaya dapat dihemat tanpa menimbulkan permasalahan lingkungan. Value engineering berfokus pada seluruh biaya pengeluaran proyek infrastruktur untuk mewujudkan suatu konstruksi yang berkelanjutan (Raheem, 2018). Wao et al. (2016) telah melakukan penelitian yang berfokus pada kemampuan value engineering untuk menangani masalah lingkungan. Hasil yang didapat yaitu value engineering mampu menghemat biaya konstruksi hingga $30 \%$.

Perencanaan berdasarkan kondisi tulangan maksimum adalah hal yang paling dihindari karena di samping biaya pekerjaan yang tergolong tinggi, juga struktur cenderung mengalami kegagalan getas. Kegagalan getas tersebut terjadi karena tidak tercapainya kelelehan pada tulangan tarik dan ditandai dengan keruntuhan pada beton serat tekan secara prematur. Pada balok beton gradasi, penggunaan mutu beton rendah pada serat tarik balok diharapkan mampu mengarahkan baja tulangan untuk mencapai kelelehannya. Sementara, mutu beton tinggi pada serat tekan balok dapat memberikan penguatan kinerja balok saat memasuki fase pasca leleh hingga ultimate, sehingga kekakuan balok tidak menurun secara tiba-tiba dan terkendali dengan lebih baik dibandingkan dengan balok beton normal.

Pada penelitian ini, penulis bermaksud untuk menganalisis lebih lanjut terkait analisis biaya terhadap kinerja yang dihasilkan dari balok beton gradasi dengan penggunaan tulangan maksimum. Hal tersebut disebabkan, pada saat pelaksanaan di lapangan, kerap kali dijumpai adanya batasan penggunaan dimensi balok yang menyebabkan penggunaan rasio tulangan mendekati batas maksimum untuk mengimbangi kebutuhan kapasitas struktur. Sejauh ini, masih belum dijumpai penelitian terkait balok beton gradasi dengan penggunaan tulangan maksimum. Melalui karya ini, penulis akan memberikan gambaran perilaku balok beton gradasi yang didesain menggunakan tulangan maksimum dan dikomparasikan terhadap balok beton normal beserta pertimbangan biaya pelaksanaannya. 


\section{Metode Penelitian}

\subsection{Pembuatan Spesimen}

Spesimen yang diuji dalam penelitian ini dibagi menjadi 2 jenis, yaitu spesimen kontrol dan spesimen balok gradasi. Masing-masing jenis spesimen terbagi kembali menjadi dua, yaitu spesimen dengan ukuran 1720 x 130 x 240 mm dan spesimen balok ukuran 1400 x 130 x 195 mm. Pemilihan kedua dimensi balok tersebut dipertimbangkan berdasarkan desain rencana balok yang erat kaitannya dengan handling pembuatan dan pengujian spesimen balok di laboratorium. Hal yang diperhatikan dalam hal ini adalah berat spesimen dan kapasitas alat yang digunakan saat pengujian.

Pada Tabel 1, kode GRA adalah spesimen balok gradasi dan REF menunjukkan spesimen balok kontrol. Kode 1/2 menunjukkan bahwa balok didesain dengan lebar balok $130 \mathrm{~mm}$ dan tinggi balok $260 \mathrm{~mm}$, sedangkan balok dengan kode $2 / 3$ didesain dengan lebar balok $130 \mathrm{~mm}$ dan tinggi balok $195 \mathrm{~mm}$. Untuk kode 20, menunjukkan spesimen didesain terhadap mutu $20 \mathrm{MPa}$ dan kode 40 menunjukkan bahwa balok didesain terhadap mutu $40 \mathrm{MPa}$. Detail pengelompokan spesimen yang digunakan dapat dilihat pada Tabel 1 .

Tabel 1. Spesifikasi Spesimen Uji

\begin{tabular}{ccccc}
\hline Kode Spesimen & $\begin{array}{c}\text { Tinggi } \\
(\mathbf{m m})\end{array}$ & $\begin{array}{c}\text { Lebar } \\
(\mathbf{m m})\end{array}$ & $\begin{array}{c}\text { Panjang } \\
\text { Bentang } \\
(\mathbf{m m})\end{array}$ & $\begin{array}{c}\text { Mutu Beton } \\
(\mathbf{M P a})\end{array}$ \\
\hline GRA1/2 20 & 260 & 130 & 1720 & $20-40$ \\
GRA1/2 40 & 260 & 130 & 1720 & $20-40$ \\
GRA2/3 20 & 195 & 130 & 1400 & $20-40$ \\
GRA2/3 40 & 195 & 130 & 1400 & $20-40$ \\
\hline REF1/2 20 & 260 & 130 & 1720 & 20 \\
REF2/3 20 & 260 & 130 & 1720 & 20 \\
REF1/2 40 & 195 & 130 & 1400 & 40 \\
REF2/3 40 & 195 & 130 & 1400 & 40 \\
\hline
\end{tabular}

Penulangan balok pada pengujian eksperimental ini dibedakan menjadi empat jenis. Pada spesimen GRA1/2 20 dan REF1/2 20, tulangan pada area tumpuan yang digunakan terdiri dari konfigurasi tulangan 2 D6 dan 2 D12. Berbeda dengan spesimen GRA1/2 40 dan REF1/2 40, konfigurasi tulangan yang digunakan yaitu 2 D16, 2 D16 dan 2 D19. Spesimen GRA2/3 20 dan REF2/3 20 menggunakan tulangan $2 \mathrm{D} 10$ dan 2 D12, sedangkan spesimen GRA2/3 40 dan REF2/3 40 menggunakan konfigurasi tulangan 2 D6, 2 D16 dan 2 D19. Lebih jelasnya terkait desain penulangan balok dapat dilihat pada Gambar 1 hingga Gambar 4.
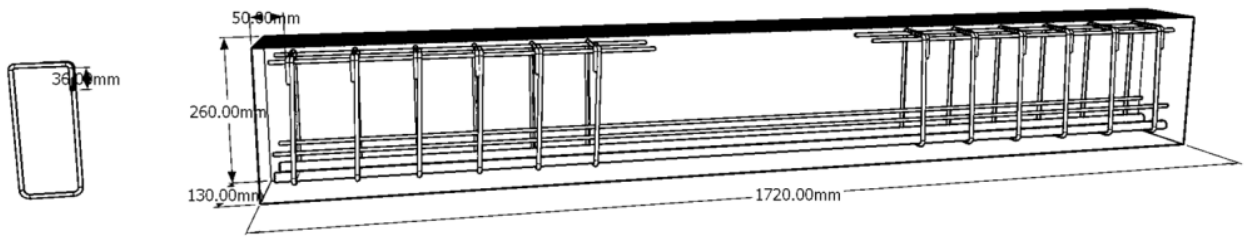

Gambar 1. Dimensi Balok dan Detail Penulangan (REF1/2 20 and GRA1/2 20) 

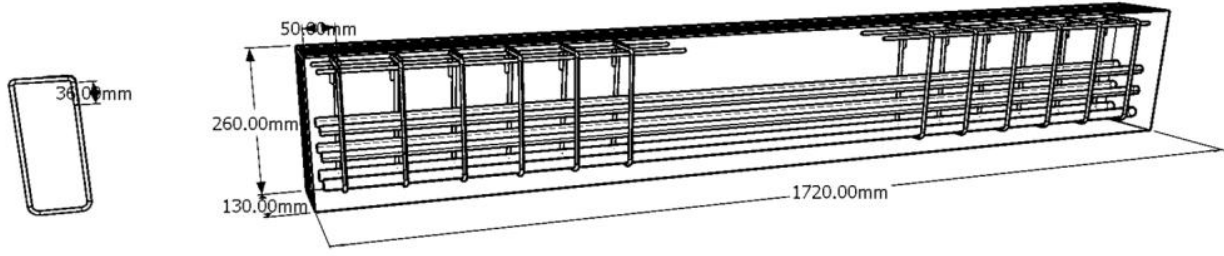

Gambar 2. Dimensi Balok dan Detail Penulangan (REF1/2 40 and GRA1/2 40)

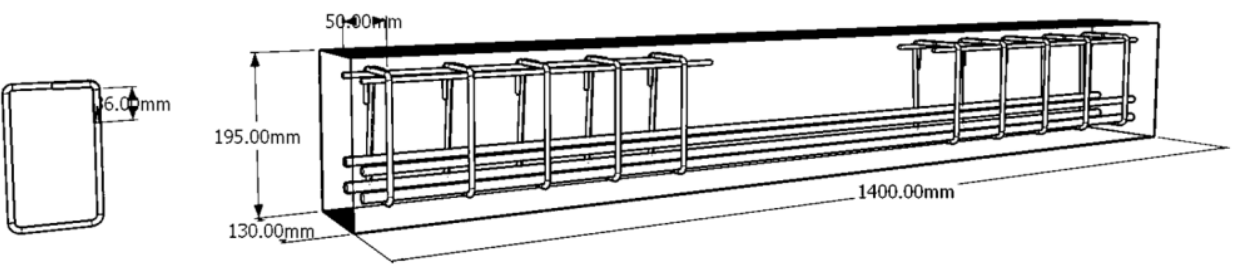

Gambar 3. Dimensi Balok dan Detail Penulangan (REF2/3 20 and GRA2/3 20)

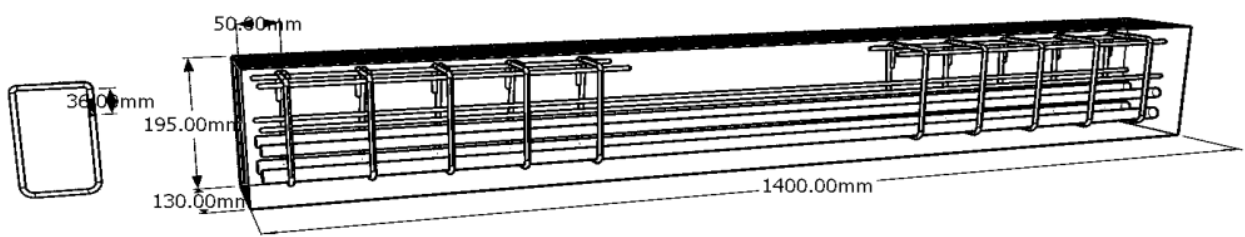

Gambar 4. Dimensi Balok dan Detail Penulangan (REF2/3 40 and GRA2/3 40)

\subsection{Mutu Beton}

Mutu beton yang digunakan adalah mutu beton $20 \mathrm{MPa}$ dan mutu beton $40 \mathrm{MPa}$. Pada beton gradasi, kedua mutu digunakan di dalam satu spesimen yang sama, dengan perbandingan antara mutu beton $20 \mathrm{MPa}$ dengan mutu beton $40 \mathrm{MPa}$ adalah 1:1, di mana mutu beton $20 \mathrm{MPa}$ diletakkan pada serat tarik dan mutu beton $40 \mathrm{MPa}$ di bagian serat tekan balok. Pemilihan mutu beton $20 \mathrm{MPa}$ dan mutu beton $40 \mathrm{MPa}$ pada spesimen balok didasarkan atas pertimbangan dan evaluasi hasil penelitian beton gradasi di tahun sebelumnya. Pada penelitian balok beton gradasi yang dilakukan oleh Pratama (2019), mutu beton yang digunakan tidak memiliki rentang mutu beton yang jauh, selisih mutu beton tertinggi dengan mutu beton terendahnya hanya terpaut $5 \mathrm{MPa}$ saja, sehingga adanya pengaruh disparitas mutu beton pada serat tarik dan serat tekan balok masih bias dan perlu dievaluasi kembali dengan menggunakan mutu beton yang memiliki selisih yang signifikan. Oleh karena itu, pada penelitian ini, mutu beton serat tarik dan mutu beton serat tekannya didesain dengan perbedaan selisih mutu beton yang jauh, yaitu dengan selisih mutu beton sebesar $20 \mathrm{MPa}$. Pada spesimen balok beton gradasi, mutu beton 20 MPa dituangkan terlebih dahulu di dasar permukaan balok hingga mencapai setengah dari tinggi balok. Kemudian, dilanjutkan dengan menuang mutu beton $40 \mathrm{MPa}$ di atas mutu beton $20 \mathrm{MPa}$ seperti pada Gambar 5. 


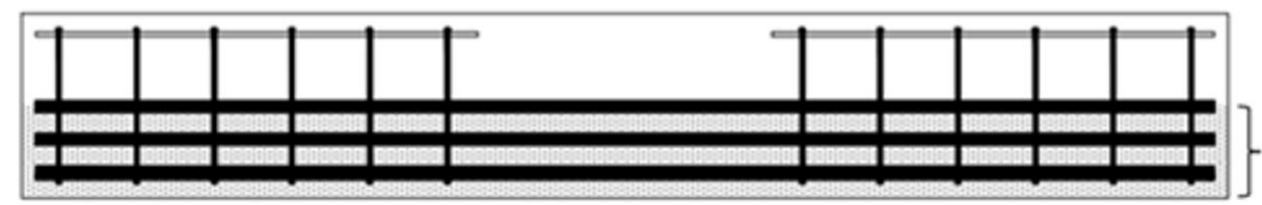

(a)

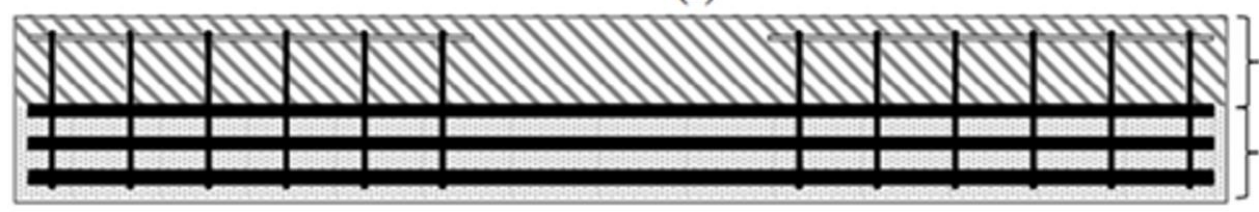

$20 \mathrm{MPa}$

(b)

Gambar 5. Pencetakan Spesimen Balok Beton Gradasi (a) Lapisan beton mutu 20 MPa; (b) Lapisan beton mutu 40 Mpa

\subsection{Metode Mencetak Balok}

Pada penelitian yang telah dilakukan Purnamasari (2015), dilakukan empat jenis metode dalam mencetak balok, yaitu: 1) Tanpa pemadatan; 2) Penggetaran akhir; 3) Pemadatan penggetaran bertahap atau vibrasi bertahap serta 4) Tamping bertahap. Teknik pemadatan yang dilakukan pada spesimen gradasi maupun spesimen kontrol pada penelitian ini yaitu dengan mengkombinasikan teknik pemadatan tamping bertahap dan pemadatan dengan menggunakan palu karet (Gambar 6). Teknik pemadatan ini merujuk pada Standar Nasional Indonesia 2493 Tahun 2011. Tujuan dari teknik pemadatan tamping bertahap adalah agar massa beton mampu mengisi celah antar tulangan, sedangkan tujuan dari penggunaan palu karet dalam proses pemadatan spesimen balok yaitu bertujuan untuk meminimalisir adanya gelembung udara pada sisi luar balok yang berhadapan dengan permukaan bekisting, harapannya diperoleh permukaan spesimen yang rata. Palu karet yang digunakan pada teknik pemadatan penelitian ini yaitu palu karet seberat $0.6 \mathrm{~kg}$ $\pm 0.2 \mathrm{~kg}$. Pemadatan dengan menggunakan palu karet dilakukan sebanyak 10-15 kali per-titik. Pengetokan palu karet dilakukan arah memanjang dilakukan setiap jarak $20 \mathrm{~cm}$.

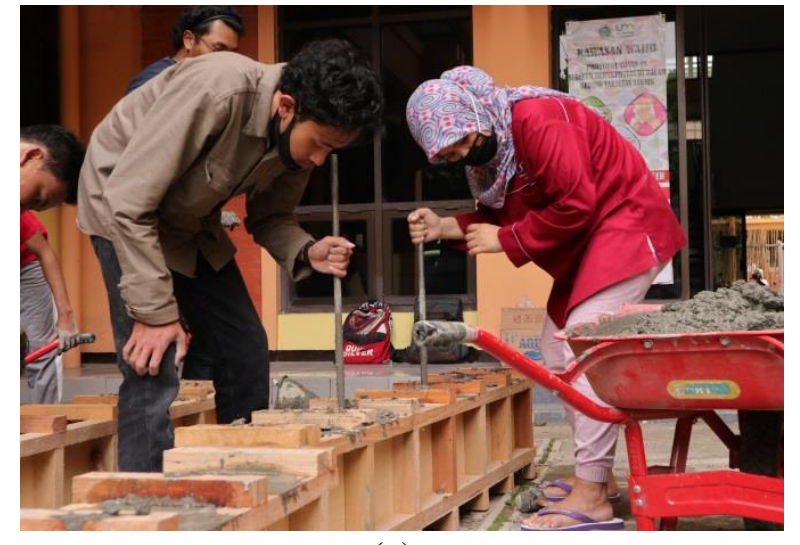

(a)

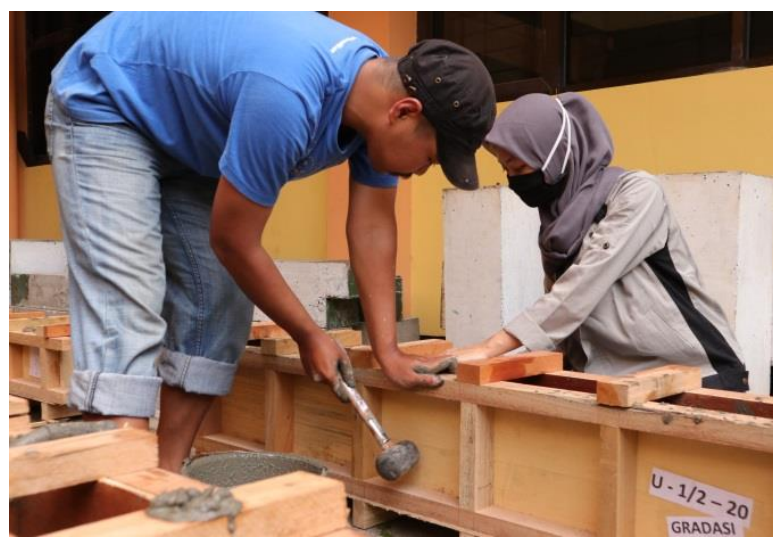

(b)

Gambar 6. (a) Teknik Pemadatan Tamping Bertahap (b) Teknik Pemadatan dengan Palu Karet

\subsection{Pengujian Lentur Balok}

Seluruh spesimen balok yang telah dicetak dan di-curing selama 28 hari dengan menggunakan karung basah, kemudian diuji secara eksperimental di Laboratorium Struktur, Universitas Negeri Malang dengan metode pengujian four-point bending. Sebelumnya, seluruh spesimen balok dicat 
dengan warna putih dan diberikan grid menggunakan tinta hitam untuk memudahkan dalam pengamatan retak. Balok diletakkan di atas tumpuan loading frame, dan dipasang instrumen pengujian seperti pompa hidrolik, load cell, spreader beam, dan dial gauge. Pembebanan dilakukan secara manual dan terkontrol melalui loading jack. Spreader beam dalam setting pengujian ini berfungsi untuk membagi beban terpusat 1 (satu) titik menjadi 2 (dua) buah beban terpusat sehingga membentuk pembebanan 4 (empat) titik (four point bending). Selama pembebanan, nilai defleksi dicatat melalui pembacaan dial gauge untuk setiap peningkatan beban yang diberikan hingga spesimen balok mengalami keruntuhan. Lebih lanjut, setting pengujian lentur balok ditunjukkan pada Gambar 7.

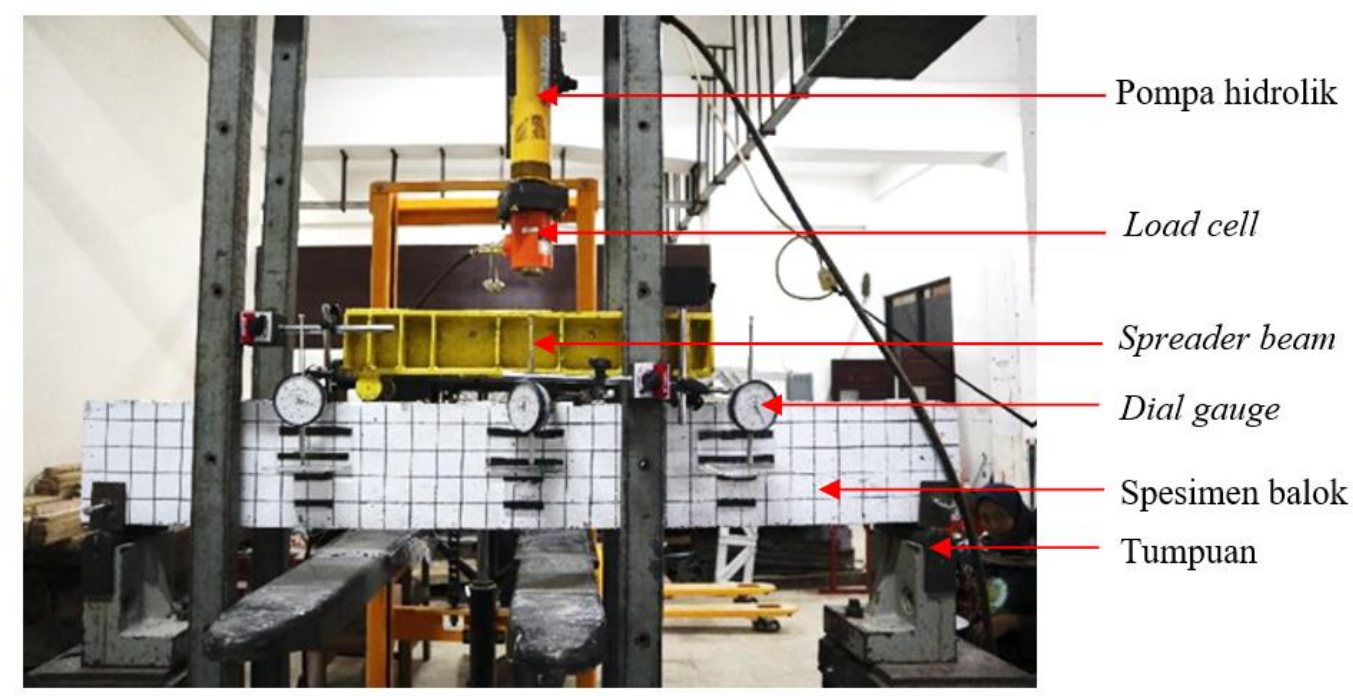

Gambar 7. Setup Pengujian Lentur Balok

\subsection{Perhitungan Biaya}

Perhitungan biaya pada spesimen balok merujuk pada Standar Harga Satuan Pekerjaan Konstruksi Pemerintah Kota Malang Tahun 2011. Penggunaan Standar Harga Satuan Pekerjaan Konstruksi Pemerintah Kota Malang didasarkan atas tempat berlangsungnya penelitian. Spesifikasi harga satuan yang ditinjau, yaitu pada penggunaan tulangan serta mutu beton yang digunakan, baik mutu beton $20 \mathrm{MPa}$ maupun mutu beton $40 \mathrm{MPa}$. Setiap tinjauan item, harga yang digunakan yaitu dihitung per $1 \mathrm{~m}^{3}$. Harga tulangan diperoleh dari pendekatan yang dilakukan dengan

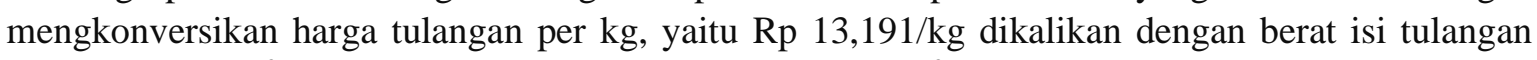
yaitu $7850 \mathrm{~kg} / \mathrm{m}^{3}$ sehingga diperoleh harga tulangan per $\mathrm{m}^{3}$. Untuk spesifikasi harga satuan yang digunakan dapat dilihat pada Tabel 2.

Tabel 2. Spesifikasi Harga Satuan

\begin{tabular}{clcc}
\hline No & \multicolumn{1}{c}{ Spesifikasi } & Satuan & $\begin{array}{c}\text { Harga Satuan } \\
\text { (Rp Juta) }\end{array}$ \\
\hline 1 & Tulangan & $\mathrm{m}^{3}$ & 103,55 \\
2 & Mutu Beton $20 \mathrm{MPa}$ & $\mathrm{m}^{3}$ & 0,95 \\
3 & Mutu Beton $40 \mathrm{MPa}$ & $\mathrm{m}^{3}$ & 1,51 \\
\hline
\end{tabular}




\section{Hasil dan Pembahasan}

\subsection{Uji Kuat Tarik Tulangan Baja}

Pengujian kuat tarik tulangan baja dilakukan dengan menggunakan Universal Testing Machine (UTM). Tulangan baja yang digunakan yaitu tulangan baja polos diameter $6 \mathrm{~mm}$ untuk tulangan sengkang, dan diameter $6 \mathrm{~mm}, 10 \mathrm{~mm}, 12 \mathrm{~mm}, 16 \mathrm{~mm}$, dan $19 \mathrm{~mm}$ untuk tulangan pada bagian serat tarik balok. Jumlah sampel masing-masing tulangan yaitu dua buah tulangan. Standar Nasional Indonesia 07-2529 Tahun 1991 terkait Metode Pengujian Kuat Tarik Baja Beton menyatakan bahwa tulangan yang diameternya melebihi $15 \mathrm{~mm}$, maka perlu dilakukan pembubutan terlebih dahulu sebelum dilakukan pengujian kuat tarik. Spesimen dengan ukuran $\varnothing 16 \mathrm{~mm}$ dilakukan pembubutan di tengah bentang sebesar $40 \mathrm{~mm}$, sedangkan spesimen dengan ukuran $\varnothing 19$ $\mathrm{mm}$ dilakukan pembubutan di tengah bentang sebesar $70 \mathrm{~mm}$. . Tabel terkait pendefinisian notasi benda uji tulangan baja dapat dilihat pada Tabel 3, sedangkan hasil uji kuat tarik baja dapat dilihat pada Tabel 4 dan Gambar 8.

Tabel 3. Pendefinisian Notasi Benda Uji Tulangan Baja

\begin{tabular}{cl} 
Kode Benda Uji & \multicolumn{1}{c}{ Keterangan } \\
\hline ST-6A & Baja tulangan dengan ukuran $\varnothing 6$ untuk kode benda uji A \\
ST-6B & Baja tulangan dengan ukuran $\varnothing 6$ untuk kode benda uji B \\
ST-10A & Baja tulangan dengan ukuran $\emptyset 10$ untuk kode benda uji A \\
ST-10B & Baja tulangan dengan ukuran $\emptyset 10$ untuk kode benda uji B \\
ST-12A & Baja tulangan dengan ukuran $\emptyset 12$ untuk kode benda uji A \\
ST-12B & Baja tulangan dengan ukuran $\emptyset 12$ untuk kode benda uji B \\
ST-16A & Baja tulangan dengan ukuran $\varnothing 16$ untuk kode benda uji A \\
ST-16B & Baja tulangan dengan ukuran $\emptyset 16$ untuk kode benda uji B \\
ST-19A & Baja tulangan dengan ukuran $\varnothing 19$ untuk kode benda uji A \\
ST-19B & Baja tulangan dengan ukuran $\varnothing 19$ untuk kode benda uji B \\
\hline
\end{tabular}

Tabel 4. Data Hasil Uji Tarik Tulangan Baja

\begin{tabular}{ccccccccc}
\hline $\begin{array}{c}\text { Kode } \\
\text { Benda } \\
\text { Uji }\end{array}$ & $\begin{array}{c}\text { Beban } \\
\text { Leleh }\end{array}$ & $\begin{array}{c}\text { Beban } \\
\text { Ultimate }\end{array}$ & $\begin{array}{c}\text { Reg. } \\
\text { Leleh }\end{array}$ & $\begin{array}{c}\text { Reg. } \\
\text { Ultimate }\end{array}$ & $\begin{array}{c}\text { Teg. } \\
\text { Leleh }\end{array}$ & $\begin{array}{c}\text { Teg. } \\
\text { Ultimate }\end{array}$ & $\begin{array}{c}\text { Rerata } \\
\text { Teg. } \\
\text { Leleh }\end{array}$ & $\begin{array}{c}\text { Rerata } \\
\text { Teg. } \\
\text { Ultimate }\end{array}$ \\
\cline { 2 - 9 } & $(\mathbf{k N})$ & $(\mathbf{k N})$ & & & $(\mathbf{M P a})$ & $\mathbf{( M P a )}$ & $\mathbf{( M P a )}$ & $\mathbf{( M P a )}$ \\
\hline ST-6A & 10.19 & 14.53 & 0.004 & 0.210 & 366.23 & 522.50 & 352.71 & 507.54 \\
ST-6B & 9.37 & 13.61 & 0.001 & 0.172 & 339.20 & 492.59 & & \\
\hline ST-10A & 27.79 & 41.92 & 0.003 & 0.242 & 374.40 & 564.74 & 379.53 & 570.40 \\
ST-10B & 28.56 & 42.79 & 0.003 & 0.201 & 384.67 & 576.46 & & \\
\hline ST-12A & 36.98 & 56.16 & 0.003 & 0.201 & 343.80 & 522.15 & 345.82 & 517.30 \\
ST-12B & 38.12 & 56.16 & 0.003 & 0.201 & 347.84 & 512.46 & & \\
\hline ST-16A & 40.62 & 62.08 & 0.004 & 0.230 & 206.56 & 315.72 & 201.91 & 312.19 \\
ST-16B & 38.01 & 59.48 & 0.003 & 0.189 & 197.26 & 308.66 & & \\
\hline ST-19A & 53.66 & 81.16 & 0.002 & 0.179 & 200.85 & 303.57 & 200.85 & 313.02 \\
ST-19B & 53.66 & 86.10 & 0.003 & 0.172 & 200.85 & 322.28 & & \\
\hline
\end{tabular}




\subsection{Kuat Tekan Silinder Beton}

Pengujian kuat tekan silinder beton dilakukan dengan menggunakan Universal Testing Machine (UTM) dan Compression Testing Machine (CTM). Jumlah sampel masing-masing mutu yaitu tiga buah silinder beton. Kuat tekan yang direncanakan, yaitu menggunakan mutu beton $20 \mathrm{MPa}$ dan $40 \mathrm{MPa}$. Pengujian kuat tekan pada spesimen beton silinder yang berumur 28 hari dilakukan untuk mengetahui kekuatan aktualnya. Seluruh spesimen silinder beton diberi kode CL. Makna angka 20 dan 40 menunjukkan jenis material mutu beton yang digunakan pada spesimen. Kode A, $\mathrm{B}$ dan $\mathrm{C}$ digunakan sebagai pembeda antara spesimen satu dengan yang lainnya pada satu jenis mutu beton. Hasil pengujian kuat tekan beton silinder dapat dilihat pada Tabel 5 .

Tabel 5. Data Hasil Uji Kuat Tekan Silinder

\begin{tabular}{ccccc}
\hline Nama Spesimen & Sampel & $\begin{array}{c}\text { Beban } \\
\text { Maksimum }\end{array}$ & Kuat Tekan & $\begin{array}{c}\text { Rerata Kuat } \\
\text { Tekan }\end{array}$ \\
\cline { 3 - 5 } & & $(\mathbf{k N})$ & $(\mathrm{MPa})$ & $(\mathrm{MPa})$ \\
\hline \multirow{2}{*}{$\begin{array}{c}\text { Beton Silinder 20 } \\
\text { MPa }\end{array}$} & CL-20A & 340.8 & 20.41 & \\
& CL-20B & 381.3 & 21.57 & 21.23 \\
& CL-20C & 383.7 & 21.70 & \\
Beton Silinder 40 & CL-40A & 720 & 40.73 & \\
MPa & CL-40B & 738 & 41.75 & 40.73 \\
& CL-40C & 702 & 39.71 & \\
\hline
\end{tabular}

\subsection{Capaian Beban Balok}

Data berupa bacaan beban diperoleh dari uji lentur secara four point bending. Dari hasil pengujian spesimen, data yang akan dikaji adalah nilai beban saat kondisi ultimate. Pengujian lentur balok dilakukan secara eksperimental di Laboratorium Struktur Jurusan Teknik Sipil Gedung D19 Universitas Negeri Malang.

Tabel 6. Capaian Beban Ultimate Balok

\begin{tabular}{lccc}
\hline Kelompok & Kode & Beban Ultimate $(\mathbf{k N})$ & Persentase Beban (\%) \\
\hline \multirow{4}{*}{ Gradasi } & GRA1/2 20 & 107.98 & +10.15 \\
\cline { 2 - 4 } & GRA1/2 40 & 118.94 & +17.65 \\
\cline { 2 - 4 } Kontrol & GRA2/3 20 & 66.46 & +199.38 \\
& GRA2/3 40 & 78.19 & \\
\cline { 2 - 4 } & REF1/2 20 & 79.88 & +56.33 \\
\hline
\end{tabular}

Berdasarkan Tabel 6, dijumpai balok GRA1/2 40 pada kondisi ultimate memiliki kapasitas beban $10.15 \%$ lebih besar jika dibandingkan dengan GRA1/2 20. Capaian beban GRA2/3 40 melampaui balok GRA2/3 20 dengan selisih persentase sebesar 17.65\%. Peningkatan rasio penulangan balok berbanding lurus terhadap capaian beban yang dihasilkan. Hal tersebut sesuai dengan penelitian Tee at al. (2016), di mana adanya peningkatan rasio tulangan mengakibatkan peningkatan hasil capaian beban spesimen balok. Perolehan beban tertinggi dicapai oleh balok yang didesain dengan 
menggunakan rasio penulangan sebesar $4.06 \%$. Dengan semakin meningkatnya nilai rasio tulangan, maka semakin berkurang nilai tegangan yang terjadi pada spesimen balok. Dengan semakin berkurangnya nilai tegangan, maka mekanisme keruntuhan spesimen balok juga semakin lambat.

\subsection{Analisis Cost Benefit Spesimen Balok}

Desain balok dengan rasio dimensi 2/3 mampu meningkatkan kinerja balok sebesar 3.57\% dengan penambahan biaya sebesar 3.69\%. Peningkatan kinerja dan penambahan biaya tersebut ditunjukkan oleh spesimen dengan rasio dimensi $2 / 3$ yang pembesiannya dirancang terhadap mutu beton terendah, yaitu mutu beton $20 \mathrm{MPa}$. Dijumpai balok dengan rasio dimensi $2 / 3$ lebih banyak diaplikasikan di lapangan. Saleem (2010) menginvestigasi pengaruh variasi dimensi balok dalam rangka memperoleh desain balok yang ekonomis. Tinjauan pada penelitian Saleem (2010) berfokus pada balok yang kerap diimplementasikan di lapangan yaitu balok dengan rasio dimensi $1 / 3$ dan $2 / 3$. Dari segi arsitektural, kelebihan yang dimiliki balok dengan rasio dimensi $2 / 3$ yaitu balok akan memberikan tinggi antar lantai yang lebih lega. Pelaksana kontruksi juga dapat menempatkan pemasangan tulangan yang lebih banyak pada arah horizontal sehingga tidak diperlukan jumlah lapis tulangan yang lebih banyak. Lapis tulangan itu sendiri dapat mengurangi lengan gaya yang nantinya akan mengurangi momen kapasitas balok yang dirancang. Berdasarkan data analisis beban dan biaya (Tabel 7), adanya upgrade spesimen kontrol ke spesimen gradasi menyebabkan peningkatkan biaya dan kinerja balok secara proporsional. Penerapan balok gradasi dapat mengakomodasi peningkatan kinerja tanpa perlu mengubah dimensi elemen sehingga diperoleh dimensi struktur yang tetap, namun dengan perolehan benefit berupa peningkatan kinerja yang selaras dengan peningkatan biaya yang dialokasikan. Guna memvalidasi temuan terkait peningkatkan biaya dan kinerja balok yang proporsional, penelitian ini dapat dikembangkan dengan memvariasikan mutu beton rendah dan mutu beton tinggi pada balok beton gradasi.

\section{Tabel 7. Persentase Perbandingan Cost Benefit Spesimen Balok Gradasi dengan} Balok Kontrol

\begin{tabular}{|c|c|c|c|c|c|}
\hline \multirow[b]{2}{*}{ Kode } & \multirow{2}{*}{$\begin{array}{c}\text { Beban } \\
\text { Ultimate }\end{array}$} & \multirow{2}{*}{$\begin{array}{c}\text { Biaya / m }{ }^{3} \\
\text { (Rp Juta) }\end{array}$} & \multicolumn{2}{|c|}{ Persentase (\%) } & \multirow{2}{*}{$\begin{array}{c}\begin{array}{c}\text { Rasio } \\
\text { \%Beban }\end{array} \\
\text { \%Biaya }\end{array}$} \\
\hline & & & Beban & Biaya & \\
\hline GRA1/2 20 & 107.98 & 6.78 & \multirow{2}{*}{+26.02} & \multirow{2}{*}{+35.17} & \multirow{2}{*}{0.11} \\
\hline REF1/2 20 & 79.88 & 6.52 & & & \\
\hline GRA1/2 40 & 118.94 & 17.83 & \multirow{2}{*}{-33.91} & \multirow{2}{*}{-25.32} & \multirow{2}{*}{0.05} \\
\hline REF1/2 40 & 159.27 & 18.06 & & & \\
\hline GRA2/3 20 & 66.46 & 7.42 & \multirow{2}{*}{+3.57} & \multirow{2}{*}{+3.69} & \multirow{2}{*}{1.02} \\
\hline REF2/3 20 & 64.09 & 7.15 & & & \\
\hline GRA2/3 40 & 78.19 & 17.78 & \multirow{2}{*}{-28.14} & \multirow{2}{*}{-21.95} & \multirow{2}{*}{0.06} \\
\hline REF2/3 40 & 100.19 & 18.02 & & & \\
\hline
\end{tabular}

Selanjutnya, penerapan gradasi mutu dapat menurunkan biaya pekerjaan hingga $25.32 \%$ dengan kompensasi kinerja sebesar $33.91 \%$ pada balok dengan rasio dimensi $1 / 2$ yang pembesiannya didesain terhadap mutu beton tertingginya. Perkembangan saat ini, upaya dalam mengurangi biaya pekerjaan konstruksi masih tetap dilakukan. Tinggi penampang minimum tidak memberikan efek pengurangan biaya pekerjaan konstruksi, terutama apabila desain panjang bentang balok terbilang kecil. Dalam riset milik Saleem (2010) juga disebutkan bahwa, spesimen balok dengan tulangan rangkap tidak selalu memberikan alokasi biaya yang lebih rendah jika dibandingkan tulangan tunggal. Adanya penurunan rasio lebar penampang terhadap tinggi $(\mathrm{b} / \mathrm{h})$ berpeluang menurunkan 
biaya pekerjaan konstruksi. Berdasarkan referensi lain, Kurda (2019) mengatakan bahwa dalam mencapai hasil yang paling ekonomis diperlukan proses-proses optimasi. Harapannya suatu elemen struktur yang dalam hal ini berupa balok dapat didesain dengan harga struktur yang murah namun tetap memenuhi adanya faktor keamanan suatu elemen struktur bangunan.

Hingga saat ini belum ada standar yang menjadi dasar perancangan balok beton gradasi sehingga hingga saat ini karakterisasi perilaku balok gradasi masih terus diinvestigasi lebih lanjut. Berdasarkan hasil penelitian yang dilakukan, upaya peningkatan kinerja elemen struktur balok dengan tulangan maksimum dapat dilakukan dengan mendesain balok dengan rasio dimensi $1 / 2$ dan tulangan dirancang terhadap mutu beton tertingginya. Konsep perancangan tersebut akan memberikan peningkatan kinerja yang proporsional terhadap tambahan biaya yang dialokasikan, dengan tetap mempertahankan dimensi elemen eksisting. Perlu digarisbawahi bahwa, fokus riset ini hanya terbatas pada kajian balok beton gradasi yang didesain amenggunakan tulangan maksimum. Hasil berbeda dimungkinkan diperoleh apabila kajian dilakukan terhadap kondisi tulangan minimum. Oleh karena itu, kajian lebih lanjut diperlukan untuk mengkonfirmasi hal tersebut.

\section{Kesimpulan}

Dari hasil penelitian ini, dapat disimpulkan bahwa dengan rasio dimensi 2/3, penambahan biaya konstruksi sebesar 3.69\% akan meningkatkan kinerja balok sebesar $3.57 \%$ apabila pembesiannya didesain terhadap mutu beton terendahnya. Penerapan gradasi mutu dapat menurunkan biaya pekerjaan hingga $25.32 \%$ dengan kompensasi kinerja sebesar $33.91 \%$ pada balok dengan rasio dimensi $1 / 2$ yang pembesiannya didesain terhadap mutu beton tertingginya. Penelitian dapat dikembangkan dengan pengembangan objek penelitian berupa desain balok dengan memvariasikan mutu beton rendah dan mutu beton tinggi pada balok beton gradasi. Penelitian ini dapat dimodifikasi dengan melakukan investigasi desain balok bertulangan minimum guna menginvestigasi kinerja balok serta total biaya yang harus dikeluarkan.

\section{Ucapan Terima Kasih}

Penulis mengucapkan terimakasih kepada Universitas Negeri Malang yang telah memberikan dukungan pendanaan yang disalurkan melalui Lembaga Penelitian dan Pengabdian kepada Masyarakat (LP2M) berupa hibah penelitian PNBP Universitas Negeri Malang Tahun 2020. Penulis juga mengucapkan terimakasih kepada seluruh pihak yang telah membantu demi kelancaran penelitian ini, baik dari rekan sejawat, tenaga pendidik Laboratorium Struktur Universitas Negeri Malang dan seluruh pihak yang turut membantu demi terlaksananya penelitian ini.

\section{Daftar Pustaka}

Building code requirements for structural plain concrete (ACI 318.1-83) and commentary. (1985). International Journal of Cement Composites and Lightweight Concrete, 7(1), 60. doi:10.1016/0262-5075(85)90032-6

Ashour, S. A. (2000). Effect of compressive strength and tensile reinforcement ratio on flexural behavior of high-strength concrete beams. Engineering Structures, 22(5), 413423. doi:10.1016/s0141-0296(98)00135-7 
Kurda, R., de Brito, J., \& Silvestre, J. D. (2019). CONCRETop - A multi-criteria decision method for concrete optimization. Environmental Impact Assessment Review, 74, 7385. doi:10.1016/j.eiar.2018.10.006

Mohammed, A. A., K. Assi, D., \& Abdulrahman, A. S. (2017). Behavior of Concrete Beams Reinforced with Low Ratio of Steel Reinforcement. Journal of Structural EnginEEring Vol. 45 , No. 3

Pratama, M. M. A., Vertian, T., Umniati, B. S., Yoh., W. H. (2019). Flexural behaviour of the functionally graded concrete beams using two-layers and three-layers configuration. IOP Conference Series: Materials Science and Engineering

Purnamasari, D. (2019). Pengaruh Tekik Pemadatan terhadap Kuat Lentur Balok Beton Gradasi. Skripsi tidak diterbitkan. Fakultas Teknik Universitas Negeri Malang

Abdel-Raheem, M., Burbach, V., Abdelhameed, A., Sanchez, G., \& Navarro, L. (2018). Value Engineering and Its Applications in Civil Engineering. Construction Research Congress 2018. doi:10.1061/9780784481295.027

Saleem, K., \& Abdul-Razzaq. (2010). Decision Making To Identify Section Dimensions that Produce Economic Design For Reinforced Concrete Beams. First Engineering Scientific Conference College of Engineering University of Diyala 22-23 December 2010, pp. 268-285

HSPK Pemerintah Kota Malang. (2011). Analisa Harga Satuan Pekerjaan Konstruksi Pemerintah Kota Malang Tahun 2011

SNI 07-2529. (1991). Standar Nasional Indonesia (SNI) 07-2529 Tahun 1991 terkait Metode Pengujian Kuat Tarik Baja Beton

SNI 2847:2019. (2019). Standar Nasional Indonesia (SNI) 2847:2019 tentang Persyaratan Beton Struktural untuk Bangunan Gedung

Wao, J. O. (2017). Value Engineering Evaluation Method for Sustainable Construction. AEI 2017. doi:10.1061/9780784480502.091 
